\title{
Efek Jamur Endofit Asal Daun dan Akar Kacang Tanah terhadap Pertumbuhan dan Penghambatan Patogen Inangnya
}

\section{The effects of Endophytic Fungi from Peanut Leaves and Rootson the Host Growth and Inhibition of the Host Pathogen}

\author{
Istifadah $\mathbf{N}^{*}$ dan Sari IP \\ ${ }^{I}$ Departemen Hama dan Penyakit Tumbuhan, Fakultas Pertanian, Universitas Padjadjaran, Jl. Raya Bandung- \\ Sumedang, Jatinangor, 45363 \\ ${ }^{2}$ Alumnus Departemen HPT, Fakultas Pertanian, Unpad
}

Istifadah, N dan Sari, I.P. 2017. Efek Jamur Endofit Asal Daun dan Akar Kacang Tanah terhadap Pertumbuhan dan Penghambatan Patogen Inangnya. Jurnal Mikologi Indonesia 1 (2): 60-69.

\begin{abstract}
Abstrak
Keberadaan jamur endofit dalam jaringan tanaman dapat menguntungkan, merugikan atau tidak berpengaruh terhadap tanaman inangnya. Penelitian ini bertujuan untuk mengkaji pengaruh jamur endofit yang diisolasi dari akar dan daun kacang tanah terhadap pertumbuhan tanaman kacang tanah dan kemampuannya dalam menghambat patogen inangnya yaitu Sclerotium rolfsii dan Cercospora sp. secara in vitro. Sampel tanaman diperoleh dari daerah Panyingkiran (Kabupaten Majalengka), Jatinangor (Kabupaten Sumedang) dan Arjasari (Kabupaten Bandung). Isolat jamur endofit akar yang diperoleh diuji patogenesitasnya terhadap kecambah dan bibit tanaman kacang tanah. Isolat jamur endofit dari daun diuji patogenesitasnya dengan menginokulasikannya pada daun kacang tanah. Isolat jamur endofit akar yang bersifat non patogenik diuji kemampuan antagonistiknya terhadap $S$. rolfsii, sedangkan isolat yang berasal dari daun diuji terhadap Cercospora sp.secara in vitro. Hasil pengujian menunjukkan bahwa dari 13 isolat jamur endofit asal daun kacang tanah yang diperoleh, tiga isolat bersifat patogenik dan 10 isolat bersifat non patogenik. Semua isolat dari daun kurang efektif menekan pertumbuhan Cercospora sp. Diantara 10 isolat jamur endofit asal akar kacang tanah, sembilan isolat dapat meningkatkan pertumbuhan tanaman kacang tanah. Sebagian besar isolat jamur endofit asal akar yang diuji kurang efektif menghambat pertumbuhan $S$. rolfsii secara in vitro. Diperoleh satu isolat jamur endofit akar yaitu isolat SAE (Aspergilus sp.) yang dapat menekan pertumbuhan patogen tersebut sebesar $66.9 \%$.
\end{abstract}

Katakunci - in vitro - Cercospora sp. - kemampuan antagonistic - patogenik - Sclerotium rolfsii

\section{Abstract}

The existence of endophytic fungi in plant tissues can be beneficial, detrimental or neutral to the host plants. The aim of this research was to examine the effects of endophytic fungi isolated from peanut roots and leaves on the host growth and their abilities to inhibit the host 
pathogens, Sclerotium rolfsii and Cercospora sp. by in vitro method. Plant sampels were obtained from Panyingkiran (Majalengka), Jatinangor (Sumedang), and Arjasari (Bandung). The fungal isolates from the roots were tested their pathogenicity on the peanut seedlings. The endophyte isolates from peanut leaves were tested their pathogenicity by inoculation to the peanut leaves. The non pathogenic isolates of the root endophyes were examined their antagonistic effects on $S$. rolfsii, whereas the isolates from peanut leaves were chalanged against Cercospora sp. by in vitro method. The results showed that among 13 isolates of endophytic fungi from peanut leaves, three isolates causing necrotic lesion on inoculated peanut leaves, whilst other 10 isolates were non pathogenic. All isolates tested isolates were not effective in inhibiting the growth of Cercospora sp. in vitro. Among 10 isolates of endophytic fungi from peanut roots, nine isolates increased the growth of the peanut plant. Most of the fungal isolates were not effective in inhibiting the growth of S. rolfsii in vitro. Only one isolate of the root fungal endophyte, isolate SAE (Aspergilus sp.),that inhibited S. rolfsii by $66.9 \%$.

Key words - in vitro- Cercospora sp - antagonistic ability-pathogenic-Sclerotium rolfsii

\section{Pendahuluan}

Jamur yang berada dalam jaringan tanaman ada yang menimbulkan penyakit dan ada yang tidak menimbulkan penyakit. Jamur yang seluruh atau sebagian siklus hidupnya ada dalam jaringan tanaman tanpa menimbulkan gejala penyakit disebut jamur endofit (Stone $e t$ al. 2000, 2004; Schulz \& Boyle 2008). Sejauh ini, jamur endofit dapat ditemukan pada berbagai tanaman yang telah dikaji baik yang hidup di darat maupun di air. Komposisi komunitas jamur endofit pada suatu tanaman tergantung dari jenis tanaman inang, jenis organ/bagian tanaman dan lingkungan. Jamur endofit ada yang bersifat generalis karena dapat ditemukan pada berbagai jenis inang, namun ada juga yang bersifat inang spesifik (Stone et al. 2004; Schulz\& Boyle 2008; Suryanarayanan 2013).

Efek jamur endofit terhadap tanaman inangnya dapat bersifat negatif, netral ataupun positip. Efek negatif jamur endofit terhadap inangnya dapat berupa penghambatan pertumbuhan atau bahkan dapat menimbulkan penyakit apabila jamur tersebut sebenarnya adalah laten patogen. Banyak jamur endofit yang bersifat komensalisme yaitu mereka mendapatkan habitat dan nutrisi dari tanaman tapi mereka tidak berpengaruh terhadap tanaman inangnya (bersifat netral). Sebagian jamur endofit yang bersifat menguntungkan bagi tanaman karena dapat meningkatkan pertumbuhan tanaman, meningkatkan ketahanan tanaman terhadap lingkungan seperti kekeringan atau salinitas. Jamur endofit juga dapat menguntungkan tanaman karena dapat menekan patogen tanaman inangnya (Backman \& Sikora 2008; Schulz \& Boyle 2008; Suryanarayanan 2013; Hardoim et al. 2015).

Kacang tanah merupakan salah satu jenis tanaman kacang-kacangan yang mempunyai nilai ekonomi relatif tinggi. Di dalam jaringan tanaman ini tentunya dapat ditemukan jamur yang bersifat endofitik dan juga patogenik. Salah satu jamur patogen yang dapat menginfeksi perakaran serta pangkal batang tanaman kacang adalah Sclerotium rolfsii. Jamur patogen ini sulit untuk dikendalikan karena dapat menghasilkan sklerosia yang dapat bertahan lama pada tanah. Salah satu patogen yang sering menginfeksi daun tanaman kacang tanah dan menyebabkan bercak daun adalah Cercospora arachidicola atau C. personatum (Semangun, 2004). Penelitian ini bertujuan untuk mengkaji efek jamur endofit yag diisolasi dari perakaran dan daun tanaman kacang tanah terhadap tanaman inangnya serta efek jamur endofit akar terhadap S. rolfsii dan jamur endofit daun terhadap Cercospora sp. 


\section{Metoda Penelitian}

Penelitian dilakukan dengan metode survei dan percobaan. Metode survei digunakan untuk mengkaji frekuensi kolonisasi dan keanekaragaman jamur endofit yang diisolasi dari sampel-sampel tanaman yang diteliti. Metode percobaan digunakan untuk mengetahui efek masing-masing isolat terhadap tanaman inang, menguji potensi antagonistik isolat-isolat jamur endofit terhadap patogen penting tanaman inangnya.

\section{Pengambilan sampel dan isolasi jamur endofit}

Sampel tanaman kacang tanah diperoleh dari beberapa daerah di Jawa Barat yaitu Jatinangor (Sumedang), Sumedang, Majalengka, dan Arjasari (Kabupaten Bandung). Pada setiap lokasi pertanaman, diambil 5 tanaman sampel untuk nantinya diambil sampel akar maupun daunnya.

Sampel akar dan daun dibersihkan dengan air mengalir, kemudian akar dipotong sepanjang $1.5 \mathrm{~cm}$ dan daun dipotong dengan luas $1 \mathrm{~cm}^{2}$. Potongan sampel tersebut kemudian didesinfestasi dengan cara dicelupkan kedalam larutan alkohol 95\% selama 1 menit, kemudian direndam dalam larutan khlorox yang mengandung 2\% khlorin selama 3-5 menit. Setelah itu dicelupkan ke dalam larutan alkohol 96\% selama 30 detik. Untuk meyakinkan bahwa tidak ada kontaminasi epifit, dibuat imprint dengan cara menekan-nekan akar yang telah didesinfestasi pada medium agar. Potongan sampel kemudian diletakkan pada media Malt Ekstrak Agar dan Potato Dextrose Agar (PDA) 1/2 strength yang telah ditambah dengan antibiotik kloramfenicol. Apabila tidak ada jamur yang tumbuh dari imprint, maka koloni jamur yang tumbuh dianggap jamur endofit. Setiap petridish diisi 10 potongan sampel (Istifadah 2005; Istifadah et al. 2008).

Frekuensi kolonisasi jamur endofit dihitung dengan menghitung persentase potongan daun yang terkolonisasi pada setiap ulangannya. Koloni jamur dengan karakteristik yang berbeda atau yang berasal dari pertanaman yang berbeda kemudian dimurnikan pada media PDA dan diidentifikasi berdasarkan karakteristik morfologinya.

\section{Uji interaksi endofit dengan tanaman inang}

Isolat-isolat jamur endofit yang diperoleh diuji pengaruhnya terhadap tanaman kacang tanah. Untuk endofit yang berasal dari akar, inokulasi dilakukan dengan cara: benih didesinfestasi dengan larutan khloroks (2\%) selama 1 menit, kemudian dibilas dengan air steril sampai tiga kali. Benih yang telah didesinfestasi diletakkan dalam biakan jamur endofit selama tiga hari (Narisawa et al. 2002). Benih yang telah diperlakukan kemudian disemai pada medium tanah dan arang sekam yang telah disterilkan dengan diautoclave $121^{\circ} \mathrm{C} 1 \mathrm{~atm}$, selama 20 menit. Tinggi tanaman, diamati setelah 2 minggu setelah inokulasi. Perakaran dan pangkal batang tanaman diamati apakah ada gejala infeksi (misalnya berupa pembusukan atau bercak coklat).

Untuk endofit pada daun, inokulasi dilakukan dengan cara point inoculation (Istifadah et al. 2006). Potongan biakan (diameter $0.8 \mathrm{~cm}$ ) yang telah diletakkan pada selotip, ditempelkan pada permukaan daun yang telah dilukai dengan ujung jarum steril kemudian diberi plastik cling wrap. Tanaman yang telah diinokulasi disungkup dengan plastik (yang telah disemprot dengan air steril) selama 24 agar kelembabannya tetap tinggi. Potongan biakan dilepaskan tiga hari setelah inokulasi dan diamati ada tidaknya gejala yang muncul.

\section{Pengujian potensi antagonistik jamur endofit nonpatogenik terhadap patogen-patogen penting tanaman inangnya}

Isolat yang bersifat non patogenik diuji efek antagonistiknya terhadap patogen penting tanaman inangnya yaitu Sclerotium rolfsii untuk endofit akar dan Cercospora sp. untuk 
endofit daun. Patogen diisolasi dari tanaman kacang tanah yang bergejala dan sebelum digunakan, telah dilakukan uji patogensitas dari isolat patogen tersebut.

Pengujian efek antagonistik jamur endofit terhadap patogen dilakukan dengan metode dual culture. Diameter koloni jamur patogen yang ke arah endofit dihitung setiap hari. Data yang diperoleh digunakan untuk menghitung Area Under Colony Growth Curve (AUCGC) (Istifadah 2005) dengan rumus yang dimodifikasi dari rumus Area Under Disease Progress Curve (Campbell \& Madden1990).

\section{Hasil}

\section{Frekuensi kolonisasi dan variabilitas isolat jamu endofit akar dan daun kacang tanah}

Hasil isolasi jamur endofit dari tanaman kacang tanah diperoleh 23 isolat yaitu 10 isolat dari akar dan 13 isolat dari daun kacang tanah. Pemberian nama isolat didasarkan pada huruf awal nama daerah asal dan bagian tanaman (akar dan daun). Frekuensi kolonisasi jamur endofit pada sampel akar dan daun kacang tanah pada penelitian ini berkisar antara 40-60\% sebagaimana ditampilkan pada Tabel 1. Jumlah potongan daun dan akar yang terkolonisasi populasi jamur endofit pada akar dan daun tidak banyak berbeda.

Tabel 1. Frekuensi kolonisasi dan variabilitas isolat jamur endofit

\begin{tabular}{lcccc}
\hline \multirow{2}{*}{ Asal daerah } & \multicolumn{2}{c}{ Frekuensi kolonisasi } & \multicolumn{2}{c}{ Jumlah isolat } \\
\cline { 2 - 5 } & akar & daun & Akar & Daun \\
\hline Jatinangor & 40 & 60 & 3 & 5 \\
Sumedang & 45 & 50 & 5 & 1 \\
Pangalengan & 50 & 45 & 1 & 5 \\
Majalengka & 50 & 40 & 1 & 2 \\
\hline
\end{tabular}

Variabiltas isolat yang diperoleh dari tanaman kacang tanah tidak terlalu tinggi. Pada sampel yang diperoleh dari masing-masing daerah paling tinggi hanya terdapat 5 jenis isolat jamur. Pada sampel dari daerah Majalengka isolat yang diperoleh hanya 1 atau 2 isolat saja. Genus jamur yang paling sering muncul dari akar tanaman kacang tanah adalah genus Fusarium dengan frekeunsi 22\% dari total sampel akar. Genus Apergillus muncul 5.5\% dari total sampel akar. Pada sampel daun, genus yangsering muncul adalah Curvularia dengan frekuensi 35\% dari total daun sampel, kemudian Apergillus (12,5\%) dan Papulaspora yang muncul pada sekitar 3\% dari total potongan daun sampel. Di antara isolat jamur yang terisolasi, ada beberapa isolat yang tidak dapat membentuk spora walaupun telah diinduksi dengan pelukaan pada koloninya atau perangsangan dengan cahaya. Isolat-isolat ini dianggap sebagai miselia sterilia.

\section{Efek jamur endofit akar dan daun kacang tanah terhadap inangnya}

Semua isolat jamur endofit akar kacang tanah dapat meningkatkan pertumbuhan tanaman inangnya terutama apabila dilihat berdasarkan variabel tinggi tanaman. Tanaman kacang tanah yang diberi perlakuan jamur endofit secara nyata lebih tinggi 1.6-2.4 kali daripada tanaman kontrol. Namun sebagian isolat tidak dapat meningkatkan berat basah akar maupun tajuk tanaman, kecuali ada empat isolat jamur yang mampu meningkatkan berat basah akar maupun tajuk secara nyata dengan peningkatan sebesar 1.7-1.9 kali dibandingkan dengan kontrol sebagaimana ditampilkan pada tabel 2.

Sebagian besar jamur endofit yang berasal dari daun tidak menimbulkan gejala ketika diinokulasikan pada daun kacang. Hal ini menunjukkan bahwa isolat tersebut bersifat non patogenik. Namun demikian, terdapat tiga isolat jamur endofit yang menimbulkan gejala ketika diinokulasikan pada daun kacang tanah sebagaimana ditampilkan pada tabel 3. Gejala yang timbul berupa bercak menguning/khlorosis pada bagian yang diinokulasi. 
Tabel 2. Efek jamur endofit terhadap pertumbuhan tanaman kacang tanah

\begin{tabular}{lcccccc}
\hline Perlakuan & \multicolumn{2}{c}{ Tinggi Tanaman } & \multicolumn{2}{c}{ Perakaran } & \multicolumn{2}{c}{ Tajuk tanaman } \\
& $\begin{array}{c}\text { Tinggi } \\
\text { tanaman } \\
(\mathbf{c m})\end{array}$ & $\begin{array}{c}\text { Dibanding- } \\
\text { kan dengan } \\
\text { kontrol } \\
\text { (kali) }\end{array}$ & $\begin{array}{c}\text { Berat basah } \\
\text { (g) }\end{array}$ & $\begin{array}{c}\text { Dibanding- } \\
\text { kan dengan } \\
\text { kontrol } \\
\text { (kali) }\end{array}$ & $\begin{array}{c}\text { Berat basah } \\
\text { (g) }\end{array}$ & $\begin{array}{c}\text { Dibanding- } \\
\text { kan dengan } \\
\text { kontrol } \\
\text { (kali) }\end{array}$ \\
\hline Kontrol & $11.8 \mathrm{a}$ & & $0.57 \mathrm{a}$ & & $2.26 \mathrm{a}$ & \\
$\mathrm{JAB}$ (Aspergilus) & $20.3 \mathrm{~b}$ & 1.7 & $1.04 \mathrm{abc}$ & 1.8 & $3.22 \mathrm{abc}$ & 1.4 \\
$\mathrm{JAI}$ (Aspergilus) & $20.3 \mathrm{~b}$ & 1.7 & $0.82 \mathrm{abc}$ & 1.4 & $3.07 \mathrm{abc}$ & 1.4 \\
$\mathrm{JAE}$ (Fusarium) & $28.0 \mathrm{~cd}$ & 2.4 & $1.25 \mathrm{bc}$ & 2.2 & $4.40 \mathrm{c}$ & 1.9 \\
Isolat SAA & $21.0 \mathrm{~b}$ & 1.8 & $1.1 \mathrm{bc}$ & 1.9 & $2.80 \mathrm{ab}$ & 1.2 \\
SAB (Fusarium) & $21.7 \mathrm{~b}$ & 1.8 & $0.87 \mathrm{abc}$ & 1.5 & $2.82 \mathrm{ab}$ & 1.2 \\
SAC (Fusarium) & $28.2 \mathrm{~d}$ & 2.4 & $1.34 \mathrm{c}$ & 2.4 & $3.81 \mathrm{bc}$ & 1.7 \\
SAD (Fusarium) & $23.0 \mathrm{bcd}$ & 2.0 & $1.27 \mathrm{bc}$ & 2.2 & $4.03 \mathrm{bc}$ & 1.8 \\
SAE (Fusarium) & $26.0 \mathrm{bcd}$ & 2.2 & $1.17 \mathrm{bc}$ & 2.1 & $3.79 \mathrm{bc}$ & 1.7 \\
MAA (Fusarium) & $21.7 \mathrm{~b}$ & 1.6 & $0.64 \mathrm{a}$ & 1.1 & $2.60 \mathrm{ab}$ & 1.2 \\
PAA (Fusarium) & $23.3 \mathrm{bcd}$ & 2.0 & $0.86 \mathrm{abc}$ & 1.5 & $3.70 \mathrm{bc}$ & 1.6 \\
\hline Ket & & & & & \\
\hline
\end{tabular}

Keterangan: Angka satu kolom yang diikuti huruf sama tidak beda nyata berdasarkan Uji Tuckey's HSD (5\%)

Tabel 3. Efek jamur endofit asal daun kacang tanah terhadap inangnya

\begin{tabular}{ll}
\hline \multicolumn{1}{c}{ Isolat Jamur Endofit } & Patogenisitas \\
\hline Kontrol & - \\
Isolat MDB & Non patogenik \\
Isolat MDC (Papulaspora) & Non patogenik \\
Isolat JDA (Curvularia) & Non patogenik \\
Isolat JDC (Aspergillus) & Non patogenik \\
Isolat JDD (Papulaspora) & Non patogenik \\
Isolat PDA (Aspergillus) & Non patogenik \\
Isolat PDB (Papulaspora) & Non patogenik \\
Isolat PDC & Non patogenik \\
Isolat PDD (Curvularia) & Non patogenik \\
Isolat PDE & Patogenik \\
Isolat JDE & Patogenik \\
Isolat JDF & Patogenik \\
\hline
\end{tabular}

\section{Efek jamur endofit asal akar dan daun kacang tanah terhadap patogen inangnya}

Sebagian besar isolat jamur endofit yang diperoleh dari akar kacang tanah kurang efektif dalam menghambat partumbuhan patogen $S$. rolfsii. Isolat-isolat tersebut hanya dapat menghambat jamur patogen yang diuji sebesar 14.7-36.2 \%. Hanya satu isolat yaitu dari genus Aspergillus yang dapat menghambat pertumbuhan $S$. rolfsii sebesar $66.9 \%$ sebagaimana disajikan pada tabel 4.

Pada uji efek antagonistik terhadap jamur patogen daun kacang, Cercospora sp., ternyata semua isolat jamur endofit daun yang diuji tidak efektif menghambat patogen tersebut. Sebanyak lima isolat jamur endofit bahkan tidak dapat menghambat pertumbuhan koloni Cercospora sp.. Pertumbuhan koloni patogen pada perlakuan dengan isolat tersebut tidak berbeda secara nyata dengan control sebagaimana ditampilkan pada tabel 5. Pada perlakuan dengan lima isolat jamur endofit yang lainnya, walaupun pertumbuhan koloni patogen secara nyata lebih lambat dibandingkan kontrol, namun penghambatan terbesar terhadap pertumbuhan koloni jamur patogen hanya sebesar $19.9 \%$. 
Tabel 4. Efek jamur endofit akar kacang tanah terhadap jamur patogen $S$. rolfsii

\begin{tabular}{lcc}
\hline \multicolumn{1}{c}{ Perlakuan/Isolat } & $\begin{array}{c}\text { Rata-rata nilai } \\
\text { AUCGC }\end{array}$ & $\begin{array}{c}\text { Persentase } \\
\text { penghambatan (\%) }\end{array}$ \\
\hline JAB (Aspergilus) & $121.6 \mathrm{~cd}$ & 28.5 \\
JAI (Aspergillus) & $132.4 \mathrm{bc}$ & 22.1 \\
JAE (Fusarium) & $108.4 \mathrm{~b}$ & 36.2 \\
PAA (Fusarium) & $125.6 \mathrm{~cd}$ & 26.1 \\
SAA & $124.4 \mathrm{bcd}$ & 26.8 \\
SAB (Fusarium) & $116.4 \mathrm{bcd}$ & 31.5 \\
SAC (Fusarium) & $136.4 \mathrm{~d}$ & 19.8 \\
SAD (Fusarium) & $145,0 \mathrm{bcd}$ & 14.7 \\
SAE (Aspergillus) & $56.2 \mathrm{a}$ & 66.9 \\
MAA (Fusarium) & $132.4 \mathrm{~cd}$ & 22.1 \\
Kontrol & $170.0 \mathrm{e}$ & \\
\hline
\end{tabular}

Keterangan: Angka satu kolom yang diikuti huruf sama tidak beda nyata berdasarkan Uji Tuckey’s HSD (5\%)

Tabel 5. Efek jamur endofit daun kacang tanah terhadap jamur patogen Cercospora sp.

\begin{tabular}{lcc}
\hline \multicolumn{1}{c}{ Perlakuan/Isolat } & $\begin{array}{c}\text { Rata-rata nilai } \\
\text { AUCGC }\end{array}$ & $\begin{array}{c}\text { Persentase } \\
\text { penghambatan (\%) }\end{array}$ \\
\hline PDB (Papulaspora) & $102.2 \mathrm{a}$ & 17.2 \\
MDB & $100.6 \mathrm{ab}$ & 18.5 \\
JDA (Curvularia) & $98.8 \mathrm{a}$ & 19.9 \\
PDA (Aspergillus) & $120.6 \mathrm{~d}$ & 2.3 \\
JDC (Aspergillus) & $111.2 \mathrm{a}$ & 8.4 \\
PDC & $120.6 \mathrm{~d}$ & 2.3 \\
PDD (Papulaspora) & $111.8 \mathrm{a}$ & 10.8 \\
JDB (Papulaspora) & $116.0 \mathrm{~cd}$ & 6.0 \\
JDD (Papulaspora) & $113.0 \mathrm{bcd}$ & 8.4 \\
MDC (Papulaspora) & $114.0 \mathrm{bcd}$ & 7.6 \\
Kontrol & $123.8 \mathrm{~d}$ & - \\
\hline
\end{tabular}

Keterangan: Angka satu kolom yang diikuti huruf sama tidak beda nyata berdasarkan Uji Tuckey’s HSD (5\%)

\section{Pembahasan}

Pada penelitian ini variabilitas jamur endofit yang diisolasi dari akar dan daun tanaman kacang tidak terlalu tinggi. Sebagian besar isolat yang diperoleh dari akar tanaman kacang adalah genus Fusarium. El-Maghraby et al. (2010) juga menemukan bahwa Fusarium adalah genus jamur endofit yang paling dominan pada perakaran Leguminaceae yaitu kacang tanah, alfalfa dan buncis. Genus ini juga banyak ditemukan di dalam jaringan perakaran tanaman seperti cabai, kubis dan jagung (Istifadah \& Suganda 2010; Istifadah et al. 2008). Walaupun genus tersebut namanya mirip dengan patogen, namun isolat Fusarium yang diperoleh tidak menghambat pertumbuhan tanaman bahkan beberapa isolat dapat meningkatkan pertumbuhan kacang tanah secara nyata. Jamur Fusarium endofitik telah dilaporkan dapat memacu pertumbuhan tanaman seperti pada Solanum nigrum (Khan et al. 2015), kacang kapri/Pisum sativum (Šišić et al. 2017).

Sebagian besar jamur endofit akar kacang tanah dapat meningkatkan pertumbuhan inangnya. Jamur endofit akar dari tanaman lain seperti dari tomat, cabai (Istifadah \& Suganda 2010) juga kentang (Istifadah et al. 2017) juga banyak yang dapat meningkatkan pertumbu- 
han tanaman inangnya. Banyak jamur endofit memang termasuk kelompok jamur pemacu pertumbuhan atau Plant Growth Promoting Fungi/PGPF dan diketahui dapat mengeluarkan hormon pertumbuhan misalnya Indole Acetic Acid (IAA), giberelin sehingga dapat memacu pertumbuhan tanaman (Hyakumachi \& Kubota 2003).

Walaupun sebagian besar isolat jamur endofit daun yang diperoleh tidak bersifat patogenik, namun ada tiga isolat yang menimbulkan gejala ketika diinokulasikan pada daun kacang tanah. Isolat-isolat tersebut kemungkinan merupakan laten patogen yang pada saat isolasi dalam kondisi laten namun apabila lingkungan mendukung, jamur tersebut dapat bersifat patogenik. Istifadah (2005) juga menemukan jamur yang biasa menyebabkan bercak coklat pada gandum, Pyrenophora tritici-repentis, dapat hidup sebagai endofit pada daun gandum sehat. Hal ini berarti jamur tersebut bersifat endofitik hanya sementara atau bersifat endofit fakultatif. Suryanarayanan dan Murali (2006) juga menemukan patogen kacang tanah Leptosphaerulina crassiasca pada daun kacang tanah yang sehat atau tidak bergejala. Adanya isolat-isolat yang dapat bersifat patogenik ini menjadi bahan pertimbangan dalam pengelolaan tanaman. Tanaman harus didukung agar kondisinya optimal bagi pertumbuhannya mengingat laten patogen biasanya akan berkembang apabila kondisi inangnya lemah (Schulz \& Boyle 2008).

Pada penelitian ini, ternyata hampir semua isolat jamur endofit yang diperoleh kurang efektif dalam menekan pertumbuhan patogen kacang tanah. Hanya satu isolat yaitu jamur endofit dari akar kacang tanah yaitu Aspergillus sp. yang dapat menekan pertumbuhan dari $S$. rolfsii. Patogen ini sangat cepat pertumbuhannya sehingga isolat jamur endofit seperti Fusarium yang pertumbuhannya relatif lambat tidak dapat menekan patogen tersebut. Aspergillus isolat SAE sporanya dapat menyebar dengan mudah sehingga dengan cepat membentuk koloni-koloni baru. Hal ini mendukung kemampuannya dalam mengkompetisi dan menekan patogen yang cepat pertumbuhannya seperti $S$. rolfsii. Selain itu, penekanan oleh isolat Aspergillus kemungkinan dapat juga karena adanya metabolit sekunder yang bersifat antimikrobia. Verma et al. (2014) melaporkan bahwa endofitik Aspergillus flaviceps yang diisolasi dari Stevia dapat menghasilkan metabolit sekunder yang menghambat Sclerotium sclerotiorum.

Hasil penelitian secara keseluruhan menunjukkan bahwa efek jamur endofit dari tanaman kacang tanah terhadap tanaman inangnya bervariasi tergatung dari jenis isolatnya. Sebagian besar isolat jamur akar memberikan efek yang menguntungkan bagi tanaman inangnya karena dapat meningkatkan pertumbuhan tanaman (sembilan isolat) dan dapat menekan patogen inangnya (satu isolat). Sebagian besar (77\%) isolat jamur endofit dari daun bersifat netral atau tidak berpengaruh secara nyata terhadap pertumbuhan tanaman kacang tanah. Tiga isolat (33\%) bersifat patogenik terhadap daun kacang. Pada uji potensi antagonistiknya, ternyata tidak ada satupun isolat jamur endofit daun kacang yang dapat menekan Cercospora sp.. Jamur endofit akar kacang tanah yaitu Apergillus isolat SAE yang dapat meningkatkan pertumbuhan maupun menekan $S$. rolfsii dapat dikembangkan lebih lanjut potensinya sebagai agen biokontrol penyakit busuk pangkal pada tanaman kacang.

\section{Ucapan Terima Kasih}

Penelitian ini merupakan bagian dari serangkaian penelitian yang didanai oleh DP2M DIKTI melalui Penelitian Fundamental.

\section{Pustaka}

Backman PA and Sikora RA 2008 - Endophytes: An emerging tool for biological control. Biological Control, $46: 1-3$

Campbell LC and Madden VL. 1990- Introduction Plant Disease Epidemiology. John Willey and Son. USA. 532p. 
El-Maghraby OMO, Soltan SM, Rehab M, Mohammed RM, Mohammed MM. 2010Endophytic fungi of three leguminous plant roots in Egypt. J. Basic and Applied. Mycology. 4: 59-68

Hardoim PR, van Overbeek LS, Berg G, Pirttilä AM, Compant S, Campisano A, Döring M, and Sessitsch A. 2015 - The hidden world within plants: ecological and evolutionary considerations for defining functioning of microbial endophytes. Microbiology Molecular Biology Review, 79: 294-306

Hyakumachi M and Kubota M. 2003 - Fungi as plant growth promoter and disease suppressor.In: Fungal Biotechnology in Agricultureal, Food and Environmental Application. Arora, DK (ed.), Marcel Dekker. Pp. 101-110

Istifadah, N dan Suganda T. 2010 - Influence of fungal endophytes on the health of several vegetable crops. In Microbial Diversity and Plant Disease Management for Sustainable Agriculture (Singh, KP and Shahi, DK Eds). VDM Verlag Dr. Muller, GmbH \& Co. KG, Germany. Pp:106-122.

Istifadah N, Suganda T dan Anggraeni R. 2008 -Jamur Endofit Daun dan Akar Jagung: Keberadaan, Pengaruhnya terhadap Tanaman Inang serta Patogen Helminthosporium turcicum Pass dan Fusarium moniliformae Sheldo. Jurnal Agrikultura, 19 : 60-65

Istifadah N. 2005 -Interactions between endophytic fungi and a wheat pathogen, Pyrenophora tritici-repentis.Thesis, S3. School of Biological Sciences, The University of Sydney, Sydney.

Istifadah N. and McGee P. 2006 - Endophytic Chaetomium globosum reduces development of tan spot in wheat caused by Pyrenophora tritici-repentis. Australasian Plant Pathology, 35: 411-418

Istifadah N, Astriani M, and Sunarto T. 2017-The potential of fungal endophytes from potatoroot and tubers to inhibit potato cyst nematode(Globodera Rostochiensis). Proceeding of International conference on Biosciences, 27-28 July,2016, Bali, Indonesia: $10-17$

Khan AR, Ullah I, Waqas M, Shahzad R, Hong SJ, Park GS, Jung BK, Lee IJ, Shin JH. 2015-Plant growth-promoting potential of endophytic fungi isolated from Solanum nigrum leaves. World J Microbiol Biotechnology, 31:1461-1466.

Narisawa K, Kawamata H, Currah RS.and Hashiba T. 2002 - Suppression of Verticillium wilt in eggplant by some fungal root endophytes. European Journal of Plant Pathology 108, 103-109

Schulz B and Boyle C.2008 - What are endophytes. In: Soil Biology, Volume 9: Microbial Root Endophytes. SchulzB, Boyle C, SieberTN (Eds.).pp. 1-10, Springer-Verlag Berlin Heidelberg.

Semangun H. 2004 - Penyakit-penyakit Tanaman Pangan di Indonesia, Gadjah Mada Press, Yogyakarta.

Šišić A, Baćanović J\& Finckh MR. 2017 -Endophytic Fusarium equiseti stimulates plant growth and reduces root rot disease of pea (Pisum sativum L.) caused by Fusarium avenaceum andPeyronellaea pinodella.European Journal of Plant Pathology,148 :271-282.

Stone JK, Bacon CW, and White JF. 2000 - An overview of endophytic mibrobes: Endophytism defined. In: Microbial Endophytes. Bacon, CW and White J F (eds.), pp. 3-30. Marcel Dekker, New York.

Stone JK, Polishook, JD, and White JF, Jr.2004 - Endophytic fungi. In Biodiversity of fungi: Inventory and monitoring methods, (eds. Mueller GM, Bills GF, and Foster, MS), Elsevier Academic Press, Amsterdam. pp. 241-270. 
Suryanarayanan TS and Murali TS. 2006 -Incidence of Leptosphaerulina crassiasca in symptomless leaves of peanut in Southern India. Journal Basic Microbiolology, 46:305-9.

Suryanarayanan TS. 2013 -Endophyte research: going beyond isolation and metabolite documentation. Fungal Ecology, 561-568

Verma A, Johri BN, and Prakash A. 2014 - Antagonistic Evaluation of Bioactive Metabolite from Endophytic Fungus, Aspergillus flavipes KF671231. Journal Mycology /371218 ID 371218, 5 pages.http://dx.doi.org/10.1155/2014/371218(accessed June 2017). 